\title{
PERUBAHAN KANDUNGAN GIZI IKAN NIKE PASCAPENGOLAHAN
}

\author{
Septian Palma Ariany, Reinal Putalan* \\ Politeknik Palu, Jalan Sinar Kemuning I Nomor 1A Bumi Roviga Tondo-Palu Sulawesi Tengah \\ Diterima: 29 November 2020/Disetujui: 23 Juni 2021 \\ *Korespondensi: reinalputalan@gmail.com
}

Cara sitasi: Ariany SP, Putalan R. 2021. Perubahan kandungan gizi ikan nike pascapengolahan. Jurnal Pengolahan Hasil Perikanan Indonesia. 24(2): 167-173.

\begin{abstract}
Abstrak
Ikan nike (Awaous melanocephalus) adalah salah satu sumber daya perikanan di perairan Sulawesi Tengah. Ikan ini juga memiliki kandungan gizi tinggi. Tujuan penelitian ini adalah untuk menentukan perubahan karakteristik proksimat dan kandungan protein serta mineral ikan nike pascaproses pengolahan panas, yang meliputi pengukusan, perebusan, dan perebusan dengan air garam. Hasil penelitian menunjukkan bahwa pengolahan yang dilakukan memberikan pengaruh yang berbeda nyata $(\alpha<0,05)$ pada komposisi proksimat, mineral, dan protein terlarut. Berdasarkan perlakuan pengolahan yang diberikan disimpulkan bahwa metode pengukusan merupakan metode pengolahan terpilih dalam penelitian ini.
\end{abstract}

Kata kunci: ikan nike (Awaous melanocephalus), mineral, pengolahan, proksimat, protein

\section{Nutritional Content of Post Processing Largesnout Goby Juvenile}

\begin{abstract}
Largesnout goby juvenile/Nike fish (Awaous melanocephalus) is a fishery resource in Central Sulawesi waters containing high nutritional content. The purpose of this study was to determine the changes in the proximate characteristics, protein and mineral content of fish after heat processing, which included steaming, boiling, and boiling with saltwater. The results showed that the processing had a significant effects $(a<0.05)$ on the proximate, mineral, and dissolved protein composition. Based on the processing treatment given, it was concluded that the steaming method was the chosen processing method in this study.
\end{abstract}

Keyword: minerals, nike fish (Awaous melanocephalus), processing, protein, proximate 


\section{PENDAHULUAN}

Kandungan gizi misalnya mineral dan protein merupakan zat gizi penting yang diperlukan oleh tubuh. Mineral dan protein berfungsi sebagai zat pembangun dan pengatur di dalam tubuh. Pemenuhan kebutuhan mineral serta protein pada manusia dapat diperoleh dengan cara mengonsumsi bahan pangan baik yang berasal dari tumbuhan (mineral nabati) maupun hewan (mineral hewani).

Ikan nike (Awaous melanocephalus) merupakan salah satu sumber daya perikanan di perairan Sulawesi Tengah. Ikan nike merupakan schooling dari yuwana A.melanocephalus. Ikan ini termasuk dalam kelompok dari famili Gobiidae (Saanin 1984). Ikan tersebut memiliki ciri-ciri tidak berwarna atau keputih-putihan serta tidak bersisik dan memiliki panjang maksimum $\pm 8 \mathrm{~cm}$ (Tantu 2001).

Ikan nike sendiri telah dimanfaatkan oleh masyarakat Sulawesi tengah sebagai sumber protein dan gizi lainnya yang bersumber dari hewani. Pemanfaatan sumber gizi hewani ini melalui tahap pengolahan panas. Proses pengolahan produk dengan panas dapat meningkatkan rasa, flavor, dan juga mampu menonaktifkan pertumbuhan mikroorganisme serta dapat memperpanjang umur simpan suatu bahan (Bognár 1998).

Penelitian mengenai dampak nutrisi terhadap kesehatan konsumen sering dilakukan pada bahan pangan mentah (segar) dengan mengabaikan proses kuliner atau pengolahan yang diterapkan pada produk pangan. Perlakuan pengolahan panas pada makanan sebelum dikonsumsi sangat penting untuk kesehatan dan nutrisi, karena meningkatkan keamanan konsumsi dan daya cerna makanan. Metode pengolahan makanan, khususnya dengan suhu tinggi, memiliki pengaruh yang besar terhadap modifikasi struktur makanan serta berkurangnya nutrisi. Efek panas mengakibatkan berkurangnya kadar air ikan sehingga memungkinkan pengawetan yang lebih baik (Hidayat et al. 2020). Selain itu, proses pengolahan juga berkontribusi pada perubahan komposisi kimia dan nilai gizinya. Kajian pengaruh metode pengolahan yang tepat terhadap perubahan kandungan kimia, protein serta mineral pada daging ikan nike perlu diketahui sehingga pemanfaatan ikan tersebut menjadi optimal. Oleh karena itu, penelitian ini bertujuan untuk menentukan perubahan karakteristik proksimat dan kandungan protein serta mineral ikan nike pascaproses pengolahan panas, yang meliputi pengukusan, perebusan, dan perebusan dengan air garam

\section{BAHAN DAN METODE Bahan dan Alat}

Bahan digunakan pada penelitian ini adalah ikan nike dari daerah desa Alindau Kabupaten Donggala Sulawesi Tengah, akuades, garam, $\mathrm{HCl}$ (Merck), $\mathrm{NaOH}$ (Merck), katalis selenium (Beta Siqma), $\mathrm{H}_{2} \mathrm{SO}_{4}$ (Merck), $\mathrm{H}_{3} \mathrm{BO}_{3}$ (Merck), n-heksana (Merck). Alat yang diperlukan antara lain tabung Sokhlet, tabung Kjeldahl, destilator, dan spektrofotometer Hach (Eterna).

\section{Metode Penelitian Preparasi sampel}

Perubahan kandungan gizi ikan nike ditentukan pada sampel ikan segar dan ikan yang diolah dengan tiga metode pengolahan. Metode-metode pengolahan yang dianalisis adalah perebusan, perebusan dengan garam $3 \%$, dan pengukusan. Tiga metode pengolahan tersebut dilakukan pada suhu $100{ }^{\circ} \mathrm{C}$ selama 8 menit. Kandungan gizi yang diamati adalah proksimat, mineral dan protein terlarut.

\section{Pengukuran proksimat}

Pengukuran proksimat ikan nike segar dan diolah dilakukan mengikuti prosedur AOAC (2005). Kadar air diukur menggunakan metode gravimetri sedangkan kadar lemak diukur menggunakan metode soxhlet. Adapun kandungan protein total diukur menggunakan metode Kjehdahl dan kadar abu menggunakan metode dekstruksi.

\section{Kadar protein (Lowry et al. 1951)}

Pengukuran kadar protein terlarut menggunakan metode Lowry dengan bovine serum albumine (BSA) sebagai protein standar. Tahapan analisis dimulai dengan pembuatan kurva standar protein BSA sedangkan larutan Lowry merupakan pencampuran dari larutan 
alkali, ion tembaga dan natrium tartrat dengan konsentrasi yang sudah diketahui. Setelah proses dilakukan, sampel ditambahkan folin. Campuran diukur absorbansinya pada panjang gelombang maksimum $(750 \mathrm{~nm})$.

\section{Kadar mineral (AOAC 2005)}

Analisis mineral dilakukan untuk mengetahui komposisi mineral makro (kalsium, magnesium, dan fosfor) dan mineral mikro (seng dan besi) yang terdapat pada ikan nike segar maupun setelah diolah. Analisis diawali dengan membuat larutan kurva standar untuk setiap mineral, sesuai dengan panjang gelombang unsur/senyawa yang dianalisis. Tahap selanjutnya adalah proses dekstruksi. Larutan uji hasil dekstruksi selanjutnya dianalisis menggunakan spektrofotometer $\mathrm{HACH}$ untuk mengetahui kadar mineral kalsium, magnesium, fosfor, seng dan besi. Nilai absorbnsi diukur pada panjang gelombang maksimum yang diperoleh. Kadar mineral ditentukan menggunakan persamaan linier yang diperoleh.

\section{Analisis Data}

Data yang diperoleh dianalisis menggunakan microsoft excel dan perangkat lunak SPSS versi 16 untuk mengetahui ratarata dan standar deviasinya.

\section{HASIL DAN PEMBAHASAN Karakteristik Ikan Nike}

Ikan nikeyang digunakan dalampenelitian ini merupakan kelompok dari famili Gobiidae, dan genus Awaous (Figure 1). Ciri-ciri dari ikan nike yaitu tidak berwarna atau keputihputihan serta tidak bersisik dan memiliki panjang minimal $2 \mathrm{~cm}$ dan maksimum \pm 8 $\mathrm{cm}$. Ikan ini merupakan ikan yang bersifat anadromous (Yamasaki \& Tachihara 2007), sehingga proses untuk penangkapannya dilakukan di muara sungai. Pada awalnya ikan tersebut menetaskan larvanya di perairan sungai, larva tersebut terbawa oleh arus sungai menuju ke laut, hidup serta berkembang hingga menjadi yuwana, selanjutnya akan kembali ke habitatnya di perairan tawar (Maie et al. 2009). Ikan nike merupakan ikanikan dari famili Gobiidea yang melakukan migrasi dalam bentuk schooling dengan tujuan menghindari pemangsaan.

Proses pengolahan panas pada ikan nike meliputi perebusan, perebusan dengan garam (3\%) serta pengukusan yang dilakukan pada suhu $100{ }^{\circ} \mathrm{C}$ selama 8 menit. Proses pengolahan panas yang diberikan berkaitan erat dengan suhu dan lama pemasakan. Suhu yang tinggi dan proses pemasakan yang lama akan menyebabkan terdenaturasinya kandungan gizi suatu bahan. Kajian mengenai pengolahan panas pada ikan diketahui bahwa perebusan atau pengukusan dapat dilakukan pada suhu sekitar $100{ }^{\circ} \mathrm{C}$ membutuhkan waktu 5-30 menit (Bognár 1998).

\section{Hasil Analisis Kimia}

Kandungan gizi merupakan parameter yang penting bagi konsumen dalam mempertimbangkan pemilihan makanan yang akan dikonsumsinya. Analisis proksimat, protein terlarut, dan mineral dilakukan untuk mengetahui nilai gizi tersebut. Hasil rerata analisis komposisi kimia dan mineral ikan nike disajikan pada Table 1 dan Table 2. Berdasarkan hasil uji keragaman (ANOVA) perbedaan proses pengolahan memberikan pengaruh yang berbeda nyata $(a<0,05)$ terhadap nilai gizi ikan nike.

Berdasarkan nilai komposisi tersebut diketahui bahwa ikan nike memiliki kadar air yang cukup tinggi, dengan kandungan protein

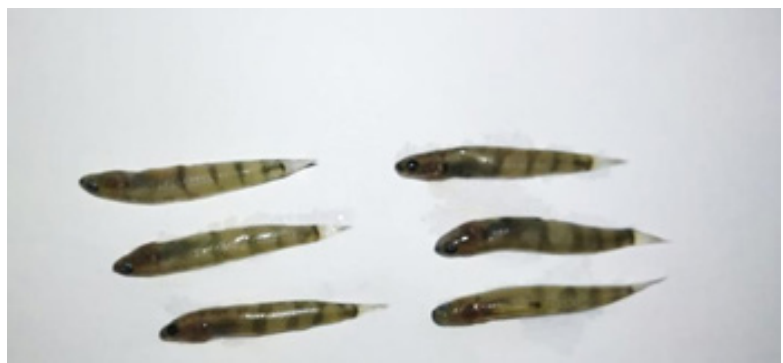

Figure 1 Nike fish (Awaous melanocephalus) 
Table 1 Chemical composition of Awaous melanocephalus juvenile

\begin{tabular}{lrrrr}
\hline \multicolumn{1}{c}{ Parameter } & \multicolumn{1}{c}{ Fresh } & \multicolumn{1}{c}{ Boiled } & \multicolumn{1}{c}{ Salted-Boiled } & \multicolumn{1}{c}{ Steamed } \\
\hline Moisture (\%) & $79.07 \pm 0.43^{\mathrm{b}}$ & $75.14 \pm 0.11^{\mathrm{a}}$ & $74.79 \pm 0.03^{\mathrm{a}}$ & $75.13 \pm 0.19^{\mathrm{a}}$ \\
Ash (\%) & $3.51 \pm 0.14^{\mathrm{b}}$ & $3.41 \pm 0.24^{\mathrm{b}}$ & $4.21 \pm 0.21^{\mathrm{c}}$ & $3.05 \pm 0.10^{\mathrm{a}}$ \\
Lipid (\%) & $2.36 \pm 0.04^{\mathrm{c}}$ & $1.19 \pm 0.00^{\mathrm{a}}$ & $1.26 \pm 0.03^{\mathrm{b}}$ & $1.19 \pm 0.01^{\mathrm{a}}$ \\
Protein (\%) & $18.73 \pm 1.13^{\mathrm{c}}$ & $15.13 \pm 0.07^{\mathrm{b}}$ & $13.34 \pm 0.39^{\mathrm{a}}$ & $18.12 \pm 0.53^{\mathrm{c}}$ \\
Soluble Protein $(\mathrm{mg} / \mathrm{g})$ & $82.98 \pm 2.12^{\mathrm{c}}$ & $16.61 \pm 3.35^{\mathrm{a}}$ & $17.52 \pm 1.00^{\mathrm{a}}$ & $32.08 \pm 0.09^{\mathrm{b}}$ \\
\hline
\end{tabular}

Note: different letter in the same row indicate significant difference $(p<0.05)$

Table 2 Mineral composition of Awaous melanocephalus juvenile

\begin{tabular}{|c|c|c|c|c|}
\hline Parameter $(\mathrm{mg} / 100 \mathrm{~g})$ & Fresh & Boiled & Salted-Boiled & Steamed \\
\hline \multicolumn{5}{|l|}{ Macro } \\
\hline Calcium & $8.50 \pm 1.32^{\mathrm{d}}$ & $2.06 \pm 0.12^{\mathrm{b}}$ & $2.06 \pm 0.12^{\mathrm{b}}$ & $5.51 \pm 0.23^{c}$ \\
\hline Phosphor & $1,181.50 \pm 37.59^{\mathrm{ab}}$ & $1,018.24 \pm 6.27^{c}$ & $1,018.24 \pm 6.27^{\mathrm{c}}$ & $1,047.08 \pm 8.93^{b}$ \\
\hline Magnesium & $2.60 \pm 0.40^{\mathrm{d}}$ & $1.80 \pm 0.04^{\mathrm{c}}$ & $1.80 \pm 0.04^{c}$ & $1.31 \pm 0.12^{\mathrm{b}}$ \\
\hline \multicolumn{5}{|l|}{ Micro } \\
\hline Zinc & $7.62 \pm 0.14^{c}$ & $4.36 \pm 0.26^{\mathrm{a}}$ & $5.74 \pm 0.07^{\mathrm{b}}$ & $5.79 \pm 0.14^{\mathrm{b}}$ \\
\hline Iron & $272.86 \pm 3.48^{c}$ & $190.21 \pm 7.04^{\mathrm{a}}$ & $241.35 \pm 6.72^{\mathrm{b}}$ & $268.96 \pm 5.41^{b}$ \\
\hline
\end{tabular}

Note: different letter in the same row indicate significant difference $(p<0.05)$

sedang, serta lemak yang rendah. Kadar air pada ikan nike mengalami penurunan setelah proses pengolahan. Penurunan kadar air pada pengolahan perebusan menggunakan garam $4,28 \%$, perebusan $3,93 \%$, dan pengukusan sebesar 3,94\%. Hasil penelitian Nurjanah et al. (2015) dan Jacoeb et al. (2020) diketahui bahwa proses pengolahan memengaruhi kadar air dalam bahan. Hal ini karena kadar air dalam bahan merembes keluar selama proses pengolahan (pemasakan). Hasil uji Duncan menunjukkan bahwa kadar air ikan nike segar berbeda nyata dengan kadar air ikan nike setelah perebusan, perebusan dengan garam, dan pengukusan.

Kadar abu dalam bahan memiliki hubungan dengan kandungan mineral. Proses pengolahan seperti perebusan dan pengukusan mengakibatkan kadar abu pada ikan nike mengalami penurunan. Penambahan garam pada proses perebusan ikan nike menyebabkan naiknya kadar abu dalam bahan tersebut disebabkan adanya $\mathrm{NaCl}$. $\mathrm{NaCl}$ merupakan salah satu mineral yang bersifat stabil dan tidak rusak karena pengolahan, tetapi proses pengolahan sendiri dapat menyebabkan penyusutan mineral pada bahan pangan yang tidak signifikan (Nurjanah et al. 2014). Beberapa penelitian memperlihatkan adanya kenaikan kadar abu suatu bahan pangan pascaperebusan dengan penambahan garam. Penelitian Desniar et al. (2009) diketahui bahwa penambahan konsentrasi garam pada pembuatan peda ikan kembung (Rastrelliger kanagurta) berbanding lurus dengan naiknya kadar abu. Pemberian garam menyebabkan pertambahan jumlah mineral (natrium) di dalam daging ikan sehingga kadar abu juga mengalami peningkatan (Purwaningsih et al. 2014). Hasil analisis ragam yang dilanjutkan dengan uji Duncan diketahui bahwa proses pengolahan memengaruhi kadar abu ikan nike.

Hasil uji keragaman perbedaan proses pengolahan memberikan pengaruh yang nyata $(p<0,05)$ terhadap nilai kandungan lemak ikan nike. Kadar lemak pada ikan nike mengalami penurunan selama proses pengolahan (Table 1). Pengaruh pengolahan panas yang diberikan sebagai perlakuan dapat memecah komponenkomponen lemak menjadi produk volatil. Produk tersebut larut ke dalam air perebusan 
atau pengukusan sehingga menurunkan kadar lemak yang ada di ikan nike. Komponen volatil hasil oksidasi lemak berperan dalam menentukan karakteristik pembentukan flavor (Abdullah et al. 2015). Pada proses pengolahan yang ekstrim, asam lemak akan dikonversi menjadi hidroperoksida yang tidak stabil oleh adanya aktivitas enzim lipoksigenase. Perubahan tersebut akan berpengaruh pada nilai gizi lemak produk (Abdullah et al. 2013).

Protein pada ikan nike mengalami penurunan pascapengolahan panas. Kandungan protein baik yang dianalisis dengan Kjeldahl maupun Lowry menunjukkan perbedaan secara nyata $(p<0.05)$. Penurunan kadar protein dapat dipengaruhi oleh suhu atau lamanya waktu (Hasnidar et al. 2021). Proses pengolahan sendiri dapat mengakibatkan nilai gizi protein akan berkurang karena terbentuknya ikatan silang dalam protein dan terjadinya denaturasi protein sehingga membentuk struktur yang lebih sederhana (Abdullah et al. 2017; Nurjanah et al. 2019). Kandungan nilai gizi protein ikan nike merupakan komponen dengan jumlah terbesar setelah air serta merupakan bagian yang sangat berguna bagi manusia. Jumlah protein terlarut mengalami penurunan selama proses perebusan berlangsung (Table 1). Hal tersebut dipengaruhi oleh suhu tinggi selama proses pengolahan yang mengakibatkan protein pada bahan mengalami denaturasi dan agregrasi. Protein terlarut sendiri merupakan suatu oligopeptida atau asamasam amino yang mudah diserap oleh sistem pencernaan sedangkan protein total merupakan pengukuran kandungan nitrogen (N) dalam sampel (Purwoko 2007). Sehingga diharapkan informasi mengenai protein terlarut pada ikan nike pascapengolahan dapat menggambarkan seberapa banyak protein yang bisa dimanfaatkan oleh tubuh.

Mineral merupakan zat organik yang dibutuhkan oleh tubuh untuk membantu reaksi fungsional tubuh, misalnya untuk memelihara keteraturan metabolisme. Nilai gizi ini hanya dibutuhkan dalam jumlah kecil untuk mendukung proses tumbuh kembang tubuh. Kurang lebih $4 \%$ berat tubuh manusia terdiri atas mineral.
Komposisi mineral ikan nike baik mineral makro maupun mineral mikro disajikan pada Table 2. Dari hasil penelitian diketahui bahwa kandungan mineral pada ikan nike mengalami penurunan pascapengolahan panas yang diberikan. Penurunan kandungan mineral disebabkan oleh proses pengolahan dengan pemanasan suhu dan media uap air. Menurut Nurjanah et al. (2014), mineral yang terkandung dalam bahan pangan akan rusak pada sebagian besar proses pengolahan karena sensitif terhadp $\mathrm{pH}$, oksigen, dan panas atau kombinasi keduanya. Beberapa penelitian menujukkan hal serupa yaitu terjadi penurunan kandungan mineral setalah proses pengolahan panas misalnya perebusan, perebusan dengan garam serta pengukusan.

Table 2 menunjukan bahwa pada ikan nike segar kadar kalsium yang didapat adalah $8,50 \mathrm{mg} / 100 \mathrm{~g}$ namun kadar kalsium ikan nike setelah diberikan perlakuan pengolahan panas (rebus, rebus dengan penambahan garam serta pengukusan) mengalami penurunan secara berturut-turut menjadi $0,34 \mathrm{mg} / 100 \mathrm{~g}, 2,06 \mathrm{mg} / 100 \mathrm{~g}$ dan $5,51 \mathrm{mg} / 100 \mathrm{~g}$. Menurut Nurjanah et al. (2014), mineral yang terkandung dalam bahan pangan akan rusak dan berkurang pada sebagian besar proses pengolahan karena sensitif terhadap $\mathrm{pH}$, oksigen, sinar, dan panas atau kombinasi di antaranya. Hal ini menunjukan bahwa pengolahan panas contohnya perebusan dan pengukusan akan menyebabkan kehilangan mineral kalsium.

Proses pengolahan panas menyebabkan penurunan kadar fosfor pada ikan nike (Table 2). Penurunan kadar fosfor ikan nike setelah dilakukan proses pengolahan, sesuai dengan penelitian Purwaningsih et al. (2013) dan Salamah et al. (2012) yaitu beberapa hasil perikanan yang diolah dengan pengolahan panas basah mengalami penurunan mineral fosfor. Kekurangan fosfor bisa mengakibatkan tingginya risiko patah tulang. Asupan fosfor yang rendah juga dapat menghambat fungsi pembentukan tulang.

Berdasarkan hasil penelitian (Table 2), mineral dengan kandungan yang paling sedikit. Proses pengolahan berkontribusi pada perubahan kandungan elemen mineral 
pada ikan. Kandungan mineral magnesium pada ikan nike mengalami perubahan selama proses pengolahan. Selain $\mathrm{pH}$, oksigen, sinar dan panas atau kombinasi di antaranya, kadar gizi mineral juga berkurang disebabkan hilangnya air dalam bahan tersebut (PolakJuszczak 2016; Abraha et al. 2018)

Besi dan seng merupakan beberapa mineral mikro yang terdapat pada ikan nike (Table 2). Dapat diketahui bahwa mineral seperti besi dan seng yang terdapat dalam ikan nike mengalami penurunan selama proses pengolahan. Persentase kehilangan mineral besi untuk pengukusan sebesar 3,90 $\mathrm{mg} / 100 \mathrm{~g}$; perebusan tanpa garam sebesar $82,86 \mathrm{mg} / 100 \mathrm{~g}$ dan perebusan dengan garam sebesar $31,51 \mathrm{mg} / 100 \mathrm{~g}$. Hasil penelitian ini didukung oleh Purwaningsih et al. (2014), yang melaporkan bahwa metode pengukusan memberikan penurunan mineral besi paling sedikit dibandingkan dengan metode perebusan dan perebusan dengan garam pada keong matah merah. Pengukusan menyebabkan kehilangan kadar seng ikan nike paling kecil, selanjutnya secara berturut turut adalah perebusan dengan penambahan garam dan perebusan tanpa penambahan garam (Table 2). Proses perebusan menyebabkan penurunan kadar seng, hal ini dipengaruhi terdegradasinya komponen misalnya protein yang mengikat mineral khususnya seng sehingga mengakibatkan mineral tersebut terlarut pada air (Salamah et al. 2012).

\section{KESIMPULAN}

Pemberian perlakuan pengolahan panas menyebabkan perubahan kandungan kimia ikan nike. Penurunan kadar komposisi kimia terjadi pada kadar air dan kadar lemak serta protein, sedangkan kadar abu mengalami kenaikan setelah mendapatkan perlakuan perebusan dengan garam. Pengukusan adalah metode pengolahan panas yang direkomendasikan untuk pengolahan ikan nike.

\section{DAFTAR PUSTAKA}

[AOAC] Association of Official Analytical Chemist. 2005. Official Method of Analysis of The Association of Official
Analytical of Chemist. Arlington (US). Abdullah A, Nurjanah, Hidayat T, Aji DU. 2015. Fatty acid profile of jellyfish (Aurelia aurita) as a source raw material of aquatic result rich benefit. International Journal of Chemical and Biomolecular Science. 1(1): 12-16.

Abdullah A, Nurjanah, Hidayat T, Chairunisah R. 2017. Karakteristik kimiawi Meretrix meretrix, Pholas dactylus, dan Babylonia spirata. Jurnal Teknologi dan Industri Pangan. 28(1): 78-84.

Abdullah A, Nurjanah, Hidayat T, Yusefi Y. 2013. Profil asam amino dan asam lemak kerang bulu (Anadara antiquata). Jurnal Pengolahan Hasil Perikanan Indonesia. 16(2): 159-167.

Abraha B, Admassu H, Mahmud A, Tsighe N, Shui XW, Fang Y. 2018. Effect of processing methods on nutritional and physico-chemical composition of fish: a review. MOJ Food Processing \& Technology. 6(4): 376-382.

Bognár A. 1998. Comparative study of frying to other cooking techniques influence on the nutritive value. Grasas y Aceites. 49(45): $250-260$.

Desniar, Poernomo D, Wijatur W. 2009. Pengaruh konsentrasi garam pada peda ikan kembung (Rastrelliger sp.) Dengan fermentasi spontan. Jurnal Pengolahan Hasil Perikanan Indonesia. 12(1): 73-87.

Hasnidar, Tamsil A, Akram AM, Hidayat T. 2021. Analisis kimia ikan sapu-sapu (Pterygoplichthys pardalis Castelnau 1855) dari Danau Tempe Sulawesi Selatan, Indonesia. Jurnal Pengolahan Hasil Perikanan Indonesia. 24(1): 78-88.

Hidayat T, Nurjanah, Jacoeb AM, Putera BA. 2020. Aktivitas antioksidan Caulerpa sp. segar dan rebus. Jurnal Pengolahan Hasil Perikanan Indonesia. 23(3): 566-575.

Jacoeb AM, Nurjanah, Hidayat T, Perdiansyah R. 2020. Komposisi kimia dan profil asam lemak ikan layur segar penyimpanan suhu dingin. Jurnal Pengolahan Hasil Perikanan Indonesia. 23(1): 147-157.

Lowry OH, Rosebrough NJ, Farr AL, Randall RJ. 1951. Protein measurement with the Folin phenol reagent. The Journal of 
Biological Chemistry. 193(1): 265-275.

Maie T, Wilson MP, Schoenfuss HL, Blob RW. 2009. Feeding kinematics and performance of hawaiian stream gobies, Awaous guamensis and Lentipes concolor: Linkage of functional morphology and ecology. Journal of Morphology. 270(3): 344-356.

Nurjanah, Jacoeb AM, Asmara DA, Hidayat T. 2019. Phenolic compound of fresh and boiled sea grapes (Caulerpa sp.) From Tual, Maluku. Food Science Technology Journal. 1(1): 31-39.

Nurjanah, Suseno SH, Hidayat T, Ekawati Y, Paramudhita P, Arifianto. 2015. Changes in nutritional composition of skipjack (Katsuwonus pelamis) due to frying process. International Food Research Journal. 22(5): 2093-2102.

Nurjanah, Jacoeb AM, Hidayat T, Ulma RN, Puspitasari, Hidayat T. 2014. Komposisi kimia kupang merah (Musculista senhausia) segar dan rebus. Depik. 3(3): 241- 249.

Polak-Juszczak L. 2016. Effects of processing methods on the content of minerals in fish products. Journal of Elementology. 21(2): 461-470.
Purwaningsih S, Salamah E, Dewantoro R. 2014. Chemical composition and fatty acids of glodok fish by high thermal processing. Jurnal Pengolahan Hasil Perikanan Indonesia. 17(2): 165-174.

Purwoko T. 2007. Protein concentrations of sweet soysauces from Rhizopus oryzae and $R$. oligosporus fermentation without moromi fermentation. Biodiversitas, Journal of Biological Diversity. 8(3):p.223227.

Puwaningsih S, Salamah E, Riviani. 2013. The changing of chemical composition, amino acids, and taurine content at glodok fish (Periopthalmodon schlosseri). Jurnal Pengolahan Hasil Perikanan Indonesia. 16(1): 12-21.

Salamah E, Purwaningsih S, Kurnia R. 2012. Kandungan mineral remis (Corbicula Javanica) akibat proses pengolahan. Jurnal Akuatika Indonesia. 3(1): 74-83.

Tantu F. 2001. Kelimpahan Spasial-Temporal Nike (Ordo Gobioidea) di Muara Sungai Bone Gorontalo. [Tesis]. Manado (ID): Universitas Sam Ratulangi.

Yamasaki N, Tachihara K. 2007. Eggs and larvae of Awaous melanocephalus (Teleostei: Gobiidae). Ichthyological Research. 54(1): 89-91. 